\title{
The Covenant of Matrimony and Christian Family Stability in Kisumu Central Sub-Region, Kenya
}

\author{
Okeyo Okello J. Hesbon*, Dr. Richard Ayako, D.Min, Dr. Anthony Ichuloi, PhD. \\ Department of Philosophy and Religious Studies, Kisii University, Kenya.
}

*Corresponding Author: Okeyo Okello J. Hesbon, Department of Philosophy and Religious Studies, Kisii University, Kenya.

\begin{abstract}
Over the last few decades, Christian response to marriage has emerged as a significant determinant for Christian Family stability. Demand for covenantal liaisons has been diminishing despite the Church's insistence and teachings on the sanctity of marriage. The government's policies against all forms of illegal and unregistered marriages were consequently enacted to mitigate matrimonial erratic responses. These were meant to foster family stability; which has not been the case. This study sought to examine the relationship between matrimony and Christian family stability in Kisumu Central Sub-Region. The study adopted a mixed methods design involving correlational and descriptive approaches. The target population was obtained from 26 Churches under the National Council of Churches of Kenya (NCCK), with a target population of 10,997. The sample size was 462 respondents obtained using the fisher's formula. Snowball as a form of purposive sampling was adopted to identify respondents. Stratified sampling was used to get the number of respondents in every Church. Semi- structured questionnaires, key informant interview schedules and Focus Group Discussions were adopted. Responses in the questionnaires were tabulated, coded and processed using computer Statistical Package for Social Science program version 22 for quantitative data analysis. Qualitative data was analyzed thematically. Descriptive statistics such as mean and standard deviation were employed, together with inferential statistics such as Pearson's Correlation and Multiple Linear Regression. The study established a positive relationship between response of Christians to the Covenant of Matrimony and family stability. In conclusion, the relationship between the Covenant of Matrimony and stability of Christian families in Kisumu Central Sub-Region was found to be positive. The study recommends advancement of awareness seminars to champion creation and strengthening of an independent Christian matrimony association to strategically create viable programs that advocate, administer and promote best matrimonial response practices to foster stable Christian families.
\end{abstract}

Key words: Covenant, Matrimony, Christian Family, Stability.

Abbreviations: FDG: Focus Group Discussion, NCCK: National Church Council of Kenya, NIV: New International Version, NSO: Negative Sentiment Override, SDG: Sustainable Development Goal

\section{INTRODUCTION}

\subsection{Christian Responses to Matrimonial Covenants and Family Stability.}

In the context of a covenant, matrimony is a socio-religious and legal contract between a man and woman (Gallagher, 2002) ordained by God to enable humans to be co-creators with God. This is reiterated by Christ when he taught that marriage between a man and woman was part of the original design of creation to continue with God's creative act (Matthew 19). For this to be realized, marriage has to be stable; it has to have no disruption, disturbance, breakage or termination through permanent separation or divorce (Berscheid \& Regan, 2016; Magwa \& Obare, 2017).

Christian Couples have a divine command to multiply, be fruitful, co-rule and subdue the earth (Gen 1:26-28). This command functions within the context of divine experiences which ought to be at the core of believers' response to the covenant of marriage. In other words, the Christian message disallows marital instabilities either through discord or disintegrations; vices known to compromise godliness and unity in societies (Van Dijk, 2017). Such stability provides a context and an enabling environment for procreation and nurturing of children (Eph.6:1-2). Stability of Christian marriages as a divine command is therefore, explicated by Quinn (2001) in his theory of divine command. Quinn 
explains that what God has commanded ought to be held in high esteem and followed through by believers.

Further, marriage is designed as a godly outlet for companionship, consummated in sexual intimacy and fulfillment (Vangelisti, 2012). This companionship is characterized by friendship, fondness and affection between spouses as key factors as further advanced by Gottman's (1999) theory of sound relationship House. This theory was therefore applied in this study to reinforce the need for the bond required between couples for a functional marriage couple companionship. Profoundly, the covenantal end of marriage depicted above, emanates from Biblical exigency that it is not good for man to be alone. Therefore and God decided to make a woman as an intimate companion to man for life (Gen. 2:18-24-NIV; 1 Cor. 7:2). It is on the basis of these two ends (procreation and companionship) that the sanctity of marriage enhanced by divine laws against adultery were constituted to mitigate family instabilities and matrimonial disintegrations (Lev. 18; 20:10).

The enactment of these divine laws fits well within the context of divine command theory by Quinn (2001) that enucleates this study. Since God has commanded and instituted the sexual offences laws described in scripture, for the sustenance of functional stable marriages, Christians, in exercise of divine commands, have an obligation to obey these laws as guidelines for their successful marriages (Evans, 2004). Such divine laws promote the permanency and sexual exclusivity as essential elements without which marriage fails to meet its course (Kanyowa, 2003). This is underscored by the bible in its re-enforcement of indissolubility and stability of marriages by admonishing men to enjoy life with their wives all their days (Eccl. 9:9). Married couples are therefore, advised to exercise happiness in their relationships to foster stability of families and avert marital breakdowns; elements which ought to inform Christian response to matrimony (Vangelisti, 2012).

Biblical texts further point to the fact that Christian matrimony is anchored in the scriptures, underlining it as an everlasting partnership covenant between a man and a woman for the whole of their lives (Randy, 2016). This partnership is further enhanced by the presence of children resulting from that relationship as established that a cord of three strands is not easily broken (Eccl. 4:12), since the parents have the responsibility together to bring up their children (Gottman, 1999). Christians are therefore, best placed to understand the ethics behind these dynamics to sustain their matrimonial responses.

Children tend to give parents satisfaction in their marriage, thus forming the ground for the stability of the family, and lessening of family related conflicts (Berlin, 2004). Based on the proper relationship of couples and the care of children; and founded on the Biblical exaltations, the Church encourages the covenantal value of marriage among couples as a mitigating factor to foster family stability (Van Dijk, 2017).

But Christians respond to the call of the covenant of matrimony in different ways; driven by the environmental social norms, such that any maladjustment of one family member is likely to affect the whole family unit and the larger unit, which is the entire society (Epstein \& McCrady, 2009). However, it is important to point out that Christians see matrimony as a sacred call which entails the elements of procreation and perpetual companionship for the building of a godly family (Heb. 13:4; 1 Cor. 7: 1-11; Ex. 20:14; Mal. 2:16). Christians further believe that marriage is a gift from God (Prov. 18:22), one that should not be taken for granted (Gen. 2: 18, 24), thus, getting married in a Church, in front of God, friends and family as witnesses, therefore, becomes imperative. This is a public declaration of love and commitment between the spouses (Amato \& Previtti, 2003). The reception of pastoral programs that augment spousal relationships and families also become imperious in their positive response to covenantal matrimony for the stability of their marriage and family affairs, although, the right way seems to be agreed upon by all practicing Christians.

The variations in response to the covenant of marriage are diverse in nature and are aligned to the post-modern lifestyle and the ever changing culture of Christianity. Some of these responses are biblebased, while others are neither Christian, nor biblical, yet the popular culture of post modernism, which influences both secular and Christian thoughts has permeated families, Kisumu notwithstanding (Noebel, 2016). This study focused on four indicators comprising Christian wedding celebrations, cohabitation, single parenthood and the practice of sexual liberation as a popular emerging thought and how they influence stability of Christian families today. 
The manner in which Christians respond to the covenant of matrimony has become a serious threat to the sanctity of marriage, denting the progress of society, particularly in Kisumu central sub-Region of Kenya. More recently, Christian response to marriage has emerged as a significant determinant for Christian Family stability. But the number of divorce, separations, cohabitative marriages and propagation of sexual liberation philosophies are on the increase. At least one in every four marriages are poised to crumble within 20 years of their wedding celebration; the Church teachings on the sanctity of marriage, and the government's policies against unregistered marriages notwithstanding. Furthermore, science and technology appear to determine almost every aspect of human life and Christian values, including matrimony, thereby leading to a drastic loss of their religious space and influence (Noebel, 2016). They embed Western secularism that has inauspiciously dented Christian family values. Subsequently, marriage is gradually losing its meaning as a covenantal relationship to the influence of modernity; the traditional and biblical goals of marriage notwithstanding. These issues are central to the response of Christians to the covenant of matrimony and are a setback to Kenya's Sustainable Development Goal (SDG) and vision 2030 which targets justifiable development of the society and excellence in all spheres. It is upon the mentioned gaps that this study endeavoured to investigate the relationship between matrimony and Christian family stability; and specifically, examine the relationship between Christian response to the covenant of matrimony and family stability in Kisumu Central Sub-region.

\section{Materials AND Methods}

\subsection{Research Design}

This study adopted a mixed methods approach involving both quantitative and qualitative elements. Correlational research approach for quantitative data was embraced to establish the cause-effect relationship between the covenant of matrimony and Christian family stability. This is in agreement with Waters (2017) who demonstrated that a correlational study is a quantitative method of research in which two or more quantitative variables from the same group of participants, are used to determine existence of a relationship (or co variation) between the two variables. Kombo and Tromp (2006) illustrated that quantitative research methods are important where data analysis is mainly statistical. This also informed the choice of this approach for the study.

Correlational research approach, therefore, was significant in measuring the Covenant of Matrimony and Christian family stability. It was also significant in evaluating the relationship between these two variables. In other words, this study was interested in looking at the degree of relationship between the two variables and not the effect of one variable on another as advanced by Kombo \& Tromp (2006).

The study also employed a descriptive survey design for qualitative data. Descriptive design allows researchers to have a brief interview or discussion with an individual about a specific topic. This enabled gathering of information, summarizing, presenting and interpreting such information for purposes of clarification as informed by Orodho (2003). The indicators that were described in qualitative data include premarital counselling programs, response of Christians to covenant of matrimony, role modelling, divorce and stability of Christian families.

\subsection{Target Population}

The study target population was obtained from 26 registered Churches in Kisumu Central SubRegion, with a total target membership of 10,997 (National Church Council of Kenya, 2020). It included married, divorced, separated couples; Church ministers and other deacon leaders of both men and women ministries, married for at least one year. These clusters of informants were all from registered protestant Churches in Kisumu Central sub region as illustrated in table 3.1.

\subsection{Sample Size and Sampling Techniques}

Following Rahi (2017), a sample is a small proportion of a population selected for observation and analysis. This study adopted the Fishers Formulae (Israel, 1992) to determine the sample size. This formulae was employed for its suitability for populations exceeding 10,000.

$$
\begin{aligned}
& n=\frac{Z^{2} p q}{d^{2}} \\
& =\frac{(1.96)^{2}(0.5)(0.5)}{(.05)^{2}}
\end{aligned}
$$


$=384$

$n=$ desired sample size when the desired sample is greater than 10,000.

$Z=$ the standard normal deviate at the required confidence level (in our case $95 \%$ ).

$p=$ the proportion in the target population estimated to have characteristics being measured (in our case 0.5 )

$q=1-p$.

$d=$ the level of statistical significance set (in our case 0.05 since the confidence level is $95 \%$ ).

One lead minister in each Church was sampled by Census, making the total number of Church ministers 26. A total of 52 other Church deacons (Men and Women leaders respectively) were further censored to participate in FGDs. Therefore, the total sample size was 462 as illustrated in table 3.2 and table 3.3.

Snowball was used to identify respondents by marital status, while stratified sampling was used to identify respondents in each of the three strata, in the specific churches. The strata were based on marital status such that the married, divorced and separated couples were each categorised per stratum. This was to ensure equitable distribution as illustrated in table 3.2 above. Married couples were the unit of analysis in this study and thus $50 \%$ of the expected sample size, which translated to 192 respondents were considered from this stratum, while the other $50 \%$ were each shared equally between divorced and separated couples.

In each church, 26 men and women leaders (Deacons) of respective men and women groups were each censored to participate in the focus group discussions. The head ministers in each Church were also censored, making a total of 26 head ministers who were identified as key informants.

\section{RESULTS AND DISCUSSION}

\subsection{Response of Christians to the Covenant of Matrimony}

The study sought to establish the relationship between the response of Christians to the covenant of matrimony and Christian family stability in Kisumu Central Sub-region. In the data analysis, the study employed the divine command theory, which helped in assessing the response of Christians in realizing the procreative call of God, guided by the biblical principle of being together in marriage, that man should not be alone, he needs a companion (Gen. 2: 18). A five point Likert scale was adopted such that: Not at all=1; Small extent $=2$; Medium extent $=3$; Large extent $=4$; Very large extent $=5$. The findings were analysed using descriptive as displayed in table 4.11.

The findings obtained showed a mean of 2.8529 , which demonstrates that Church weddings have a direct and positive relationship with Christian family stability. This is consistent with the findings by Olson et. al., (2012), which established that Church wedding participation has positive influence on the outcomes of family stability because they are mentored; while Jesse (2015) endorses that Church marriages inspire positive attitudes and attributes within individuals, which positively impact on couples' marital relationships in a way of making them stable. Wedding also act as a form of mentorship and evangelization to others who do not go to Church. These findings, however, contradict those of Mialon \& Francis (2014) and Griggs (2014) that narrowed down themselves only to financial aspects of wedding in Church, undermining other important values in marriage and family. Mialon and Francis had concluded that couples who spend less on their wedding have longerlasting marriages, thereby enduring better stability. They sweepingly claim that celebrating cheaper weddings significantly contribute to happy marriages, hence better, stable family outcomes. While lavish weddings with high overspending exerts pressure and subsequent stress that could likely become a recipe for divorce and unstable families.

Table 4.11 above also shows the results on the variable of cohabitation. The respondents were also asked to state the relationship between cohabitation and Christian family stability in the sub region. A mean of 2.9167 was obtained, which justifies that cohabitation has a direct negative relation to Christian response to the covenant of matrimony; it has a moderate relationship to Christian marriage. This is consistent with the findings by Hiekel et. al., (2014), which affirmed that cohabitation is today taken to be an alternative to Church and legal marriage and a norm that governs the start of a marriage relationship. However, the findings were inconsistent with Bumpass (1990) who acknowledged that cohabitation nurtures uncertainty about married a couples' future. In support, DeRose (2018) explains 
that cohabitation is a fragile form of union. DeRose further enunciates that children gotten out of such liaisons encounter more stigmatization and other forms of psychosomatic illnesses than those from stable and legal marriage unions.

As demonstrated in the table above, the respondents were further asked to indicate the relationship between single parenthood and Christian covenant of matrimony for family stability in Kisumu central sub region. A mean of 3.0441 was obtained. This mean results indicated that Christians have chosen to stay single instead of embracing the covenant of matrimony as advised by their respective Churches and the biblical exhortations. Based on the findings, the study, subsequently concluded that single parenthood has a moderate relationship to Christian covenant of matrimony. It adversely affects the biblical and Christian manner of responding to divine command of procreation and the responsibility in the upbringing of children born out of such family settings.

The findings were found to be inconsistent with Wallerstein \& Kelly (1980) and Hetherington, et. al., (1985) both of whom established that single parenthood damages a Christian family setup of a nuclear family under the biblical principles of man and woman; and that it is not good for a man to stay alone, rather they should couple together in marriage. Further, Webster-Stratton (2003) adds that single parenthood directly and adversely affect children who aspire to be brought up from a properly instituted form of bible based family. He further claims that the situation of single parenthood breeds the attitude of hostility in those who are divorced and also in their children, thus undesirably affecting family relationships.

Finally, the respondents were asked to indicate their agreement and disagreement of the impact of sexual liberation on marriage and family stability. This was done in order to establish the relationship between sexual liberation and Christian family stability in Kisumu Central Sub region. The results in the table above showed a mean of 2.9314 was obtained. This implied that there are those who do not support sexual freedom in marriage and family relationships. A key informant stated:

It is like 'my dress my choice' just like the way it started with abortion and some Church leaders fear such antagonists because they pay tithe regularly and so they're left to do as they wish (KII6).

The verbatim findings implies the complaints of society is against sexual liberation, which has negative impact on Christian marriages, and call for a return to African marriage ethics, in which morals were tersely safeguarded. On this, another informant from the interviews, KII4 asserted:

Loss of our traditional identity has increased erratic response to the covenant of marriage. This is because today the society does not discourage, mock or laugh at spouses who practice marital vices. They leave it as a personal issue so those who divorce, cohabit, or practice sexual liberation see it as norm (KII4).

These field findings are consistent with Tembe (2010), who explains that feminists and human rights activists advocated for sexual liberation, which has led to radical individual autonomy in making personal decisions among married couples, irrespective of the determinations of society, including the number of children to be born in a marriage. In essence, this affects considerably marriage stability and family relationships, to the height of stalling the rate of marital commitments.

Thus, a respondent P20 from the Focussed Group Discussants emphatically and critically stated that:

Divorce, single parenthood, cohabitation and sexual exploitation steals the joy of stable

Christian families and our religious leaders are not speaking strong enough on issues

that cause these among Christian families. Some married people dress as if they are still single and their pastors are very quiet about it. They know of the soap operas and Nigerian movies that make married Christians to go astray but they also do not preach strongly against these (P20).

Thus, table 4.11 above indicates the composite mean of 2.97305 for Christian responses to illustrate the relationship between the covenant of matrimony and Christian family stability in Kisumu Central Sub-region. It is a moderate relationship between the two variables.

The study findings showed that runaway female desire for independence was a variable to watch in the strategies for taming the high level of divorce. This independence was understood as independence from domestic violence, socio-economic challenges, psycho-social challenges and demeaning cultural practices. But sexual liberation was not meant to provide freedom from moral 
values and morally acceptable behavior such as marriage and family establishments. The trend taken by some spouses as using the desire for independence to divorce their traditionally or Church married husbands, cohabit, or practice sexual experimentation through sexual liberation has been perceived as an abuse of that freedom and independence.

\subsubsection{Correlation and Regression of Response of Christians to the Covenant of Matrimony}

Pearson's correlation and regression of response of Couples to the covenant of matrimony and family Stability was embraced in order to examine the relationship. The findings are demonstrated in tables 4.12, table 4.13, table 4.14 and table 4.15.

Table 4.12 illustrates that response of Christians to the covenant of matrimony recorded a Pearson's correlation of 0.752 to family stability. Hence, the study concluded that response of Christians to the covenant of matrimony is positively correlated to Christian family stability in Kisumu Central Subregion, Kenya.

Table 4.13 displays the coefficient of determination for response of Christians to the covenant of matrimony and family stability. The coefficient of determination (R2) obtained was 0.566 which is $56.6 \%$. This implies that the response of Christians to the covenant of matrimony caused a $56.6 \%$ deviation on family stability. Hence, the study concluded that response of Christians to the covenant of matrimony caused a moderate deviation on Christian family stability in Kisumu Central Subregion, Kenya.

Table 4.14 displays the model summary for response of Christians to the covenant of matrimony and Christian family stability. The F statistic obtained (8.25) is greater than the f-critical which is 7.71. This implies that the model was statistically significant. Therefore, the study concluded that relationship of response of Christians to the covenant of matrimony and Christian family stability in Churches in Kisumu Central Sub-region, Kenya was statistically significant.

Table 4.15 displays the regression coefficients for response of Christians on Pre-marital Programmes and family stability. From the findings, the resulting equation is:

$\mathrm{Y}=2.945 \mathrm{X}-5.365$

Therefore, the study concluded that there exists a positive relationship between response of Christians to the covenant of matrimony and family stability for couples in Kisumu Central Sub-region.

\section{CONClusion}

\subsection{Summary}

The study got an average mean of 2.9362 response, which revealed that there is a positive response correlation and relationship between matrimony and Christian family stability in Kisumu Central Subregion. Christians choose to respond to the covenant of matrimony in various forms; there are those who choose to wed in church, others cohabit or remain in single parenthood, in total violation of God's divine command of marriage and family union as established in Genesis chapter two. The study underlined that improper response to the marriage covenant is a challenge to the Church's marriage and family pastoral ministry. The church, apart from marriage counselling programs is challenged to devise other mechanisms that will make the covenant of matrimony relevant and attractive to the Christians.

\subsection{Conclusion of the Study}

In regard to Christian response to the covenant of marriage, the study concluded that it is an important call to Christians to passionately embrace their biblical and marriage vocation. It is true that some Christians are discouraged by marriage related difficulties encountered by married couples, but marriage challenges should not be taken to mean that the covenant of marriage itself has lost its divine nature for Christians. It is their divine calling to cooperate with God in the divine act of procreation, which can only be realized in true and authentic Christian families and environment. Christian marriage is the sure, faith-based and value loaded commitment and relationship. 


\subsection{Recommendations of the Study}

In line with the study objectives and findings; the study recommends creation and strengthening of an independent Christian matrimony association or body which shall strategically create programs to advocate, administer and promote best practices for fostering stable Christian families in Kisumu. This body will monitor, evaluate and promulgate policies on Church premarital and marital programs. This was found necessary because of the lapses identified in the manner in which those programs are implemented. The study noted the reality of the manifestation of negative attitude and ineptitude of those engaged in helping married couples, which suggests lack of proper training and evaluation that is based on Christian principles of marriage and family apostolate.

The study also recommends the creation of information technology (IT) database that will enable proper preservation and management of data related to family and marriage life. This is because, it was a challenge to find Church information regarding the covenant of marriage and related areas. The marriage programs are managed in a manner that they do not give up-to-date information on marriage in many Churches within Kisumu Central Sub-region. Such database will further facilitate detection of matrimony related issues and help in documenting Church mitigation mechanisms that ensure and propel Christian family stability.

\subsection{Suggestions for Further Studies}

The suggestions for further study are based on the salient gaps identified in this study. Thus, the study, recommends research on the following:

- The Role Of Extended Family Members On The Management Of Christian Family Affairs In Kisumu

- The Influence Of Christian Witness On The Establishment Of Authentic Stable Families In Kisumu

\section{REFERENCES}

[1] Gallagher (2002) Gender Differences in Cognitive Processing. Wiley online library Retrieved-from https://onlinelibrary.wiley.com/doi/abs/10.1002/j.2333-8504.2002.tb01886.x

[2] Berscheid, E. S. \& Regan, P. C. (2016). Psychology of Interpersonal Relationships. London: Psychology Press.

[3] Magwa, N. and Obare, F. (2017). Fertility Transitions in Ghana and Kenya: Trends, Determinants. Rockville, Maryland, USA: ICF International

[4] Van Dijk, R. (2017). "The Tent versus Lobola: Marriage, Monetary Intimacies and the new Face of Responsibility in Botswana." Anthropology Southern Africa, 40 (1): 29-42.

[5] Quinn, P. L. (2001). "Divine Command Theory." in Hugh Lafollette, Ed. The Blackwell Guide to Ethical Theory. Blackwell philosophy guides. Oxford, UK: Blackwell.

[6] Vangelisti, A. L. (2012). Interpersonal processes in romantic relationships. Retrieved on 6th March 2016 from http://www.sagepub.in/upm-data/48309_CH_18.pdf Walsh

[7] Evans, C.S., (2004). Kierkegaard's Ethics of Love: Divine Commands and Moral Obligations. Oxford University Press.

[8] Kanyowa, T.W. (2003). Family Problems Faced by Individuals with Partners Working and Living Abroad: A Case of Chinhoyi Urban, Mashonaland West Province Zimbabwe. Research on Humanities and Social Sciences www.iiste.org ISSN 2222-1719 (Paper) ISSN 2222-2863 (Online) Vol.4, No.2, 2014.

[9] Randy, S. (2016). An Introduction to the Sacrament of Matrimony and the Nuptial Blessing.-HeythropJournal. Retrieved. From https://adoremus.org/2015/11/15/introduction-sacrament-matrimony

[10] Berlin, G. (2004). The Effects of Marriage and Divorce on Families and Children. Paper Presented Before the Science, Technology and Space Subcommittee of the Committee on Commerce, Science, and Transportation, United States Senate.

[11] Epstein, E.E. \& McCrady, B.S. (2009). A Cognitive Behavioural Treatment Program for Overcoming Alcohol use Problems: Therapist Guide. New York: Oxford University Press.

[12] Amato, P. R., \& Previti, D. (2003). People Reasons Divorcing: Gender, Social Class, the Life Course, and Adjustment. Journal of Family Issues 24(5): 602-626

[13] Noebel, D. A. (2016). Understanding the Times. Manitou Springs, CO: Summit Press.

[14] Waters, J. (2017). Conducting Correlational Research. Capillano University, North Vancouver, Canada.

[15] Kombo, D.K \& Tromp, D.L.A (2006). Proposal and Thesis Writing: An Introduction. Pauline's Publications Africa. Nairobi, Kenya. 
[16] Orodho, A.J. (2003). Essentials of Educational and Social Science Research Methods. Mazola Publishers, Nairobi.

[17] National Church Council of Kenya, NCCK (2020). Report. Author.

[18] Rahi, S. (2017). Research Design and Methods: A Systematic Review of Research Paradigms, Sampling Issues and Instruments Development. International Journal of Economics \& Management Sciences, 6 (403), 359-403.

[19] Israel, G.D. (1992). Sampling the Evidence of Extension Program Impact. Program Evaluation and Organizational Development, IFAS, University of Florida. PEOD-5.

[20] Olson, D.H., Olson, A.K., \& Larson, P.J. (2012) PREPARE-ENRICH Program: Overview and new discoveries about couples. Journal of Family \& Community Ministries, 25, 30-44

[21] Jesse R. L. (2015). Christian Wedding Ceremonies: "Non-religiousness" in Contemporary Japan. Japanese Journal of Religious Studies, 42 (2), 185-203

[22] Mialon, H.M \& Francis, A.M, (2014). Correlation between Wedding Expenses and the Length of Marriages. Emory University.।

[23] Griggs, B. (2014) Weddings: Where To Skip Or Splurge. CNN. London.

[24] Hiekel Nicole, 2014, "The different meanings of Cohabitation across Europe: How Cohabiters view their unions and differ in their plans and behaviors", Amsterdam University Press, Thesis.

[25] Bumpass, L.L (1990). Interaction between demographic and institutional change. Population association of America: Presidential address. Center for Demography and Ecology, University of Wisconsin, Madison, Wisconsin 53706.

[26] DeRose, L. (2018). Marriage, Cohabitation and Family life. World Family Map Project.

[27] Wallerstein, J., and J. Kelly. 1980. Surviving the Breakup: How Children and Parents Cope with Divorce. New York: Basic Books.

[28] Hetherington, E. M., Cox M., Cox R. (1985).Long-Term Effects of Divorce and Remarriage on the Adjustment of Children. Journal of the American Academy of Child and Adolescent Psychiatry, 24(5):518-30.

[29] Webster-Stratton, C. 2003. The Incredible Years. Toronto: Umbrella Press.

[30] Tembe, M.M. (2010). An Investigation into the Causes of Divorce amongst the Evangelical Church members in Namakgale Township. South African Theological seminary, Johannesburg South Africa: Stellenbosch University (Masters Dissertation)

Citation: Okeyo Okello J. Hesbon, et.al. "The Covenant of Matrimony and Christian Family Stability in Kisumu Central Sub-Region, Kenya" International Journal of Humanities Social Sciences and Education (IJHSSE), vol 7, no. 9, 2020, pp. 85-92. doi: https://doi.org/10.20431/2349-0381.0709008.

Copyright: (c) 2020 Authors. This is an open-access article distributed under the terms of the Creative Commons Attribution License, which permits unrestricted use, distribution, and reproduction in any medium, provided the original author and source are credited. 